\title{
Atlantis
}

Critical Studies in Gender, Culture \& Social Justice

Études critiques sur le genre, la culture, et la justice

\section{Legal Solutions to Street Sexual Harassment in the \#MeToo Era}

\section{Denise Brunsdon}

Volume 39, numéro 2, 2018

URI : https://id.erudit.org/iderudit/1064071ar

DOI : https://doi.org/10.7202/1064071ar

Aller au sommaire du numéro

Éditeur(s)

Mount Saint Vincent University

ISSN

1715-0698 (numérique)

Découvrir la revue

Citer cet article

Brunsdon, D. (2018). Legal Solutions to Street Sexual Harassment in the \#MeToo Era. Atlantis, 39(2), 40-56. https://doi.org/10.7202/1064071ar

\section{Résumé de l'article}

Street sexual harassment is the unwelcome commoditization of women's bodies by fellow citizen-strangers. This harm is under-recognized by traditional, Anglocentric common law. This paper begins by discussing the \#MeToo wave, in particular by suggesting that it is a re-branded version of the feminist movement that is helpful but not sufficient to address street sexual harassment. Second, the paper outlines how street sexual harassment harms women. Third, some contextual analysis of why governments and legal systems have been slow to address street sexual harassment are provided. Fourth, the paper assesses the various areas of the law that may be used to curb street sexual harassment. Finally, this paper canvasses the ways other governments have taken action against street sexual harassment. Ultimately, this paper argues that the lack of protection of the basic civil right to use the public sphere free of sexual harassment is a failure of the Canadian justice system, and a criminal response remains essential. Other methods of legal regulation are inadequate without the social condemnation that criminal law carries.
Ce document est protégé par la loi sur le droit d'auteur. L'utilisation des services d’Érudit (y compris la reproduction) est assujettie à sa politique d'utilisation que vous pouvez consulter en ligne.

https://apropos.erudit.org/fr/usagers/politique-dutilisation/ 


\section{Legal Solutions to Street Sexual Harassment in the \#MeToo Era}

Denise Brunsdon, JD, MBA, is an associate at Bennett Jones LLP (Calgary) and is the recipient of the Queen's Golden Jubilee Medal, in particular for her gender-based community volunteer work. She has published broadly on issues of gender and technology, and gender and politics.

\begin{abstract}
Street sexual harassment is the unwelcome commoditization of women's bodies by fellow citizenstrangers. This harm is under-recognized by traditional, Anglocentric common law. This paper begins by discussing the \#MeToo wave, in particular by suggesting that it is a re-branded version of the feminist movement that is helpful but not sufficient to address street sexual harassment. Second, the paper outlines how street sexual harassment harms women. Third, some contextual analysis of why governments and legal systems have been slow to address street sexual harassment are provided. Fourth, the paper assesses the various areas of the law that may be used to curb street sexual harassment. Finally, this paper canvasses the ways other governments have taken action against street sexual harassment. Ultimately, this paper argues that the lack of protection of the basic civil right to use the public sphere free of sexual harassment is a failure of the Canadian justice system, and a criminal response remains essential. Other methods of legal regulation are inadequate without the social condemnation that criminal law carries.
\end{abstract}

Keywords: street sexual harassment; \#MeToo; street harassment; catcalling; law; sexism; feminism; Canada; United States; criminal; critical legal studies; legislation

\section{Introduction}

Street sexual harassment is the unwelcome commoditization of women's bodies by fellow citizen-strangers. Street sexual harassment can be defined as unwanted comments, gestures, and actions made in a public place related to the innocent party's perceived sex, gender, gender expression, or sexual orientation (Stop Street Harassment 2015). This includes actions such as whistling, leering, sexist slurs, persistent requests for a name or number, following, flashing, and public masturbation (Stop Street Harassment 2015). Historically, this behaviour has been described using the ungendered and non-descript term of "catcalling." The insults - or "compliments" as they may be mischaracterized by perpetrators - can be frequent but unpredictable. This consistent but randomized violence creates sizeable harm by making public space uncomfortable, even unsafe, for women. Dread of this impending violation of dignity is a state of oppression for many women.

This harm is under-recognized by traditional, Anglocentric common law. The \#MeToo wave of the feminist movement has brought a renewed interest in, and public discourse about, the oppression that mainly women face, usually at the hands of men. Personal experiences - so prominent in the \#MeToo wave-are often absent in legal discourse and, to some extent, academic research generally. The feminist movement, in contrast, relies on the power of storytelling and consciousness-raising to counteract the dominant male viewpoint. This paper explores the ways that the \#MeToo wave of feminism has raised awareness of sexual harassment, how this might bring attention to street sexual harassment in Canada, and the potential legal remedies available. 
This paper begins by discussing the \#MeToo wave, in particular by suggesting that it is a re-branded version of the feminist movement that is helpful but not sufficient to address street sexual harassment. Second, the paper outlines how street sexual harassment harms women. Third, some contextual analysis of why governments and legal systems have been slow to address street sexual harassment is provided. Fourth, the paper assesses the various areas of the law that may be used to curb street sexual harassment. Finally, this paper canvasses the ways other governments have taken action against street sexual harassment.

Ultimately, this paper argues that the lack of protection of the basic civil right to use the public sphere free of sexual harassment is a failure of the Canadian justice system, and a criminal response remains essential. Other methods of legal regulation are inadequate without the social condemnation that criminal law carries.

\section{The \#MeToo Context}

I contend that the true value of \#MeToo is not in its expression as a new "movement." Rather, \#MeToo fits within the greater feminist movement, and is not a separate movement unto itself. This article therefore labels the movement as a "wave" within the feminist movement, an approach endorsed by others (Parry 2018).

The \#MeToo wave of feminism is a modern and digitally-flourishing take on a traditional pillar of the women's movement: consciousness-raising. Women sharing their oft-similar stories of gender-based violence creates a unifying experience out of what can seem to be an individual or even invisible problem. The \#MeToo wave has created a more open social climate for discussing gender-based violence, including street sexual harassment.

Many \#MeToo stories seem to include-and responses to these stories gain oxygen from-the abuse of power. This is evident in the \#MeToo focus on Weinstein-style harassment, i.e. abuse within a relationship of unequal power. However, this focus poses a challenge to addressing issues of street sexual harassment, or sexual assault more generally, where the issue is not about an individual asserting and abusing their power over a more vulnerable colleague or date. Acts of street sexual harassment are more randomized and anonymous. Perhaps because a single incident of street sexual harassment is less destructive or violent than a rape, it is wrongly deemed innocuous. The more universal an experience in men's lives, the more often society rationalizes street sexual harassment as a harmless experience (e.g., "boys will be boys," "locker room talk," and various other anachronisms for broad-based and socially acceptable gender violence). This ignores how a hundred incidents of harassment invade the psychological safety and self-worth of women.

The genesis of \#MeToo mainly regarded the struggles of privileged, white, cis, wealthy, and often celebritized women, the root theme of this wave of the feminist movement. The lessons, however, can and should be broader. Intersectional analysis acknowledges that multiple spheres of structural disadvantage exist but cannot be understood by simply adding layers of disadvantage. Race, gender expression, and all the factors that signal non-conformity to the patriarchy's idealized woman can affect the way she is harassed and the harms she experiences. Notions of attractiveness are socialized, including social preference by race, economic status, gender expression, and physical ability. The harm from street sexual harassment varies based on social preference and status. Street sexual harassment is not reserved for women who are deemed socially desirable, and can also be used as a tool to police and demean women perceived as undesirable or nonconformist. Thus, while the \#MeToo wave of feminism has provided an important shift toward personal and widely shared stories, an intersectional feminist lens is also necessary to address street sexual harassment. 
My allergies had been just horrific, but I'd decided to brave the run across the street to the little bodega
anyway because I'd been out of dishwasher soap and milk and coffee filters for three days. As I walked
up the steps to the entrance, two men walked out. Because I'm a woman who's been trained by society
not to look strange men in the eye when its dark out and they look potentially threatening, I didn't. But
they stopped in the doorway and came up close to me, speaking far louder than was necessary. "Whoa
mama, look at those tits." "Daaaaamn. Naw like really dog, daaaaaaamn." One started masturbating and
pushed up close to my face as I stared at the ground, trying to navigate around them. He rubbed
himself and licked his lips as he undressed me with his eyes and loudly proclaimed what he'd do to me. YOUR

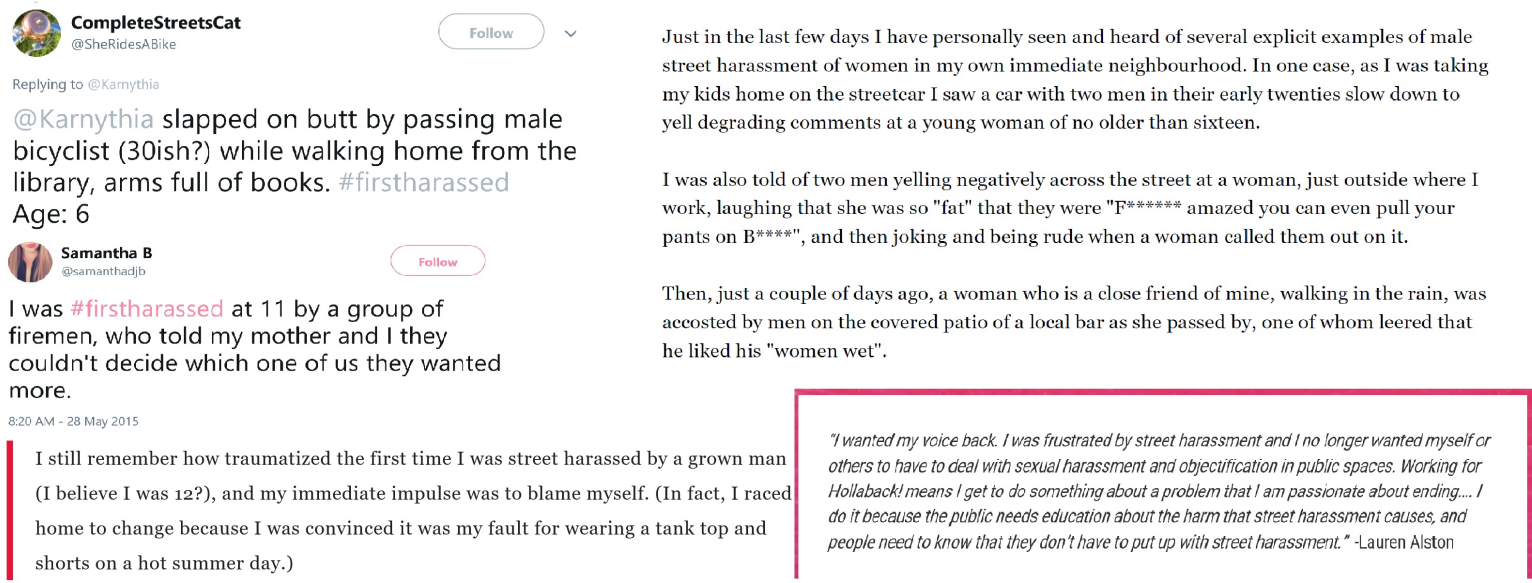

Image 1: A sample of online posts sharing thoughts about and personal experiences of street sexual harassment. (Clockwise from top left: Collazo 2013; unknown; Laxer 2013; Alston 2012; Moore 2015; Boosil 2015; CompleteStreetsCat 2015)

\section{The Harm}

Many women can still recall their first personal experience with street sexual harassment because it was traumatizing (Trudy 2013; Vinciguerra 1994). Norma Anne Oshynko wrote in her Master of Law thesis that "street harassment can best be understood as an integral part of a system of sexual terrorism which allows men to dominate and control women" (Oshynko 2002).

Street sexual harassment tells women that our presence in the public sphere is open for comment and criticism by strangers. The attacks remind women that our bodies are commodities to be freely consumed and commented upon by fellow citizens. Several scholars have argued that street sexual harassment - and the lack of legal recourse available to survivors of it-is an ongoing denial to grant women their basic human rights. Gender scholar Robert Allen wrote:

Whether in the workplace or on the street, the purpose of sexual harassment is to reduce women to objects sexually vulnerable to men, and to reestablish the traditional power relation- ship between men and women. Indeed, women's sexual vulnerability to men is a key locus of male power, something men learn to expect. (1995, 134)

As Cynthia Grant Bowman wrote in her Harvard Law Review article, street harassment is the denial of a basic civil liberty:

The most fundamental definitions of liberty include the right of an individual to go where she chooses in spaces that are public. Indeed, liberty of this sort is essential to equal participation in the affairs of the polis. The security to move about in public, what Blackstone called "the power of locomotion," is one of the most basic civil rights; it is essential to the rights to assemble and petition for redress of grievances - the primary prerequisites to participation in public affairs and admission to the public realm. Thus, when the law fails to protect women from street harassment, it deprives them of one of the basic goods for which government was ordained, leaving them in an Hobbesian wilderness men do not share. (1993, 520-21) 
More specifically, the many harms of street sexual harassment include feeling powerless, dehumanized, and isolated; fearing for one's safety; and the practical effects of changing one's daily habits, including going outside less and at more restricted times (Davis 2017; Fox 2016). No recitation of the harm flowing from street sexual harassment would be complete without noting the role that sexual harassment plays in condoning gender-based violence. Widespread objectification of women's bodies is linked to violence against women (American Psychological Association 2007; Oddone-Paolucci, Genuis and Violato 2000).

Recognizing these harms is important because damages are a key element under the law, but also because such recognition helps to stamp out the myth that some women enjoy street sexual harassment. As with other forms of sexual violence, myths exist to reinforce the acceptability of the violating conduct. That "catcalls" are inoffensive and even flattering is one such myth. New York Post writer Doree Lewak con-
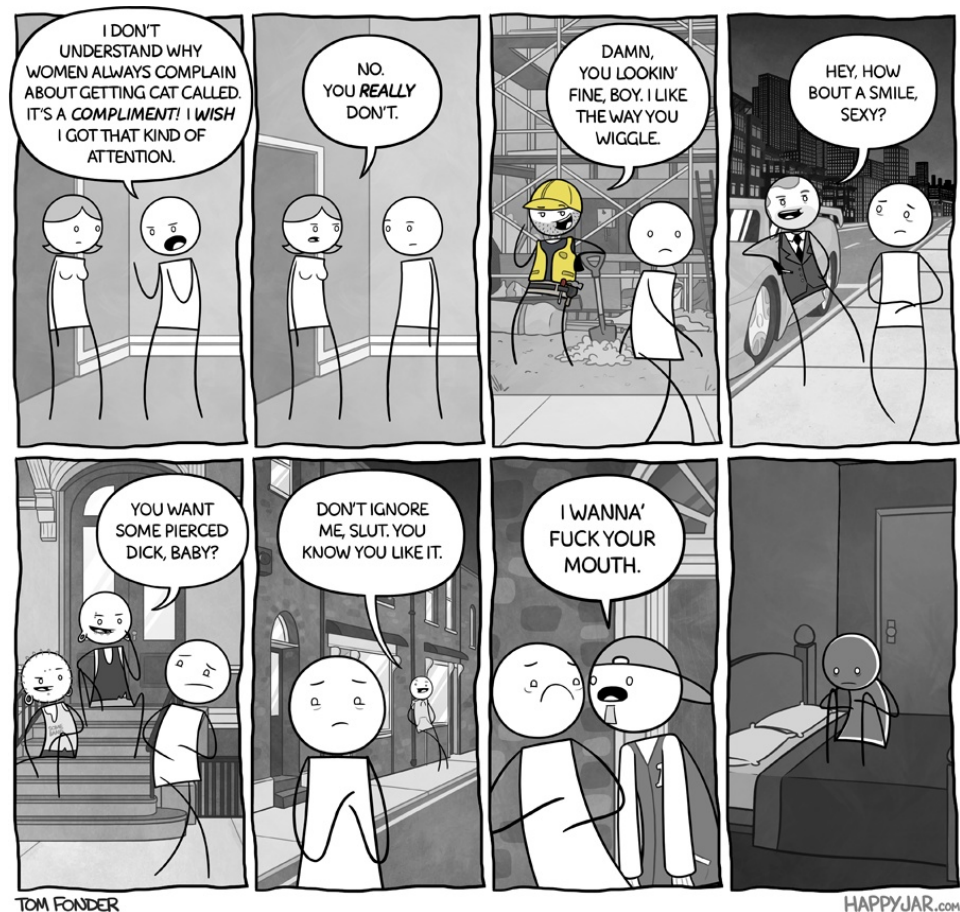

Image 2: Tom Fonder 2014 troversially wrote of street harassment as a "drive-by dose of confidence [that] is the 10-second antidote to all that negative feedback in the real world" (2014). Although some women may claim that they enjoy the experience, this does not address the lack of consent to such harassment by all women.

\section{The Statistics}

The nature of street sexual harassment makes it difficult to track; it is constant yet unpredictable. Often, the woman is alone and the only witnesses are friends of the offender. Often, the harassment comes from a moving vehicle.

Hollaback! and Cornell University began a large-scale research survey on street harassment in 2014. There were over 16,600 respondents overall, making this survey the largest analysis of street harassment to date. The study found that, globally, the majority of women experience their first incident of street harassment during puberty (Livingston 2014).

In Canada, 620 women participated in the survey: $73 \%$ reported their first experience with street harassment between the ages of 10 and 17 , and $79 \%$ of women reported being followed by a man or group of men that made them feel unsafe during the past year (Livingston 2014). Over 60\% of women reported changing their daily lives to avoid harassment, for example by taking different modes of transportation or a different route home, not going out at night, not socializing, feeling distracted at school and work, and changing the time of leaving an event or location (Livingston 2014). A 2013 Hollaback! Ottawa community consultation on street sexual harassment found that $97 \%$ of respondents had experienced harassment on the street in the past year (Hollaback! Ottawa 2013). 


\section{Relevant Academic Theories}

A primary reason for the lack of government priority given to street sexual harassment is its disproportionate effect on women. As briefly discussed below, dominance feminism best explains the lived experiences of women subjected to street sexual harassment. Critical legal studies (CLS) also helps explain why women are refused full and equal access to legal protections and why the law systematically underserves less powerful communities.

Dominance feminism emphasizes the difference in power between men and women and how men's interests dominate the agenda in a patriarchal society (Chamallas 2012). Women's lack of power means a lack of voice in state priorities and governance (MacKinnon 1983). Street sexual harassment does not often attack male dignity. The status quo allows men to engage in street sexual harassment at their whim. Thus, the current system of what is deemed acceptable street sexual harassment shoulders women with the majority of the harm. Dominance feminism explains why street sexual harassment is not mentioned in the House of Commons or newspapers (Baumgardner and Richards 2000). Such awareness would require the legislature and media to step out of the dominant male perspective.

Critical legal studies has value in dissecting discrimination within the law. CLS deconstructs the way that power embeds and recreates itself within the legal system, never devolving to the vulnerable. Critical legal theory posits that:

Legal thought originates, of course, within the consciousness of the dominant class because it is in this class' interest to bring it into being, but it is accepted and interiorized by everyone because of the traumatic absence of connectedness that would otherwise erupt into awareness. (Gabel 1992)

Feminist legal theorists would point out that the dominant class is overwhelmingly male.

\section{Relevant Canadian Law}

Sexual harassment has been recognized as an offence under the anti-sex discrimination provisions in the human rights codes present across Canada's provinces (Janzen v. Platy 1989). Freedom from sexual harassment is thus a human right in part because sexual harassment is an affront to dignity, personal integrity, autonomy, and personhood (Allen 1995; British Columbia Law Institute 2001).

Chief Justice Dickson for the Supreme Court stated in 1989 that sexual harassment is "an abuse of both economic and social power" (Janzen v. Platy 1989). Courts have recognized that sexual harassment includes leering (Webb v. Cyprus Pizza 1985), sexually suggestive gestures (Sharp v. Seasons Restaurant Ontario 1987), and derogatory or degrading remarks. These legal cases involved workplace sexual harassment, however, not street sexual harassment.

In considering street sexual harassment, one fundamental question is whether the legal response should be a matter of private or public law, as both could play a role. Broadly speaking, public law is an umbrella term to describe the areas of law that affect society as a whole, and private law regards disputes between individuals and commercial entities. After reviewing elements of private law, this paper argues that, ultimately, the social condemnation aspect of public law, in particular, the Criminal Code established by the federal government, makes it a more useful avenue to begin addressing street sexual harassment. The Criminal Code is taught to law students as the set of rules the government uses to indicate what behaviour the state condemns and will punish through a reduction in civil liberties.

\section{i. Private Law}

Feminist scholar Catharine MacKinnon (1987) wrote: "Sexual harassment, the event, is not new to women. It is the law of injuries that it is new to" (3). In a 1992 Law Society of Upper Canada (LSUC) conference paper, lawyers stated a similar idea: "There is no inher- 
ent barrier preventing resourceful counsel from conceiving a cause of action arising from circumstances wherein a client has been the victim of sexual harassment" (LSUC 1992, D-2). This progressive stance would prove naive. Sexual harassment by way of sex discrimination has been a proven tort (Lajoie v. Kelly 1997), but courts have been reticent to recognize it in other instances (Seneca College v. Bhadauria 1981). The Alberta Court of Queen's Bench said that whether the court recognized a tort of sexual harassment "is still an open question" (CampbellFowler v. Royal Trust Co. 1993). Gillian Demeyere provides a helpful summary of sexual harassment torts to date:

While courts have uniformly allowed actions for breach of contract based on alleged sexual harassment to proceed, the treatment of actions in tort has been less consistent. Some courts have declined to exercise their jurisdiction over claims asserting independently recognized torts where the conduct alleged might be also described as sexual harassment....

There can be little dispute that the wrong of sexual harassment can include the violation of interests long protected by the common law. Indeed, the pleadings approach concedes as much, by finding actions that plead independently recognized causes of action to be within the jurisdiction of common law courts. But by holding actions that plead merely "sexual harassment" to be beyond the jurisdiction of the common law, the pleadings approach implicitly declares that the wrongfulness of sexual harassment consists wholly in the fact that it is a form of sex discrimination. So understood, the common law cannot come to recognize a new tort of sexual harassment, because Bhadauria tells us that sex discrimination falls within the exclusive jurisdiction of human rights commissions. $(2005,647,663)$

The courts have recognized a tort of sexual harassment by other names, recognizing that sexually har- assing conduct is tortious. But court recognition of the explicit tort remains weak. The established torts of battery, sexual assault, nuisance, and emotional distress all hold elements relevant to street sexual harassment. As mentioned earlier in this article, sexual harassment results in a loss of dignity, autonomy, personhood, and personal integrity (BC Law Institute 2001, at 11). Additional harms flow from any of battery, assault, nuisance, or emotional distress that is sexual or gender based "including difficulties relating to depression, anxiety, mood disorders, disturbances of sleep, eating, sexuality, personality, interpersonal relationships, child development, and learning abilities" (British Columbia Law Institute 2001, 11). Tort law and its awards have recognized such damages.

Sexual assault is an accepted sexual violence tort, often seen in cases of childhood sexual abuse. Even with near-universal societal rejection of rape, Canadian courts have not awarded civil remedies for sexual assault consistently. The harm of sexual assault "has not yet been fully recognized by the civil justice system" (British Columbia Law Institute 2001). Craig Brown and Melanie Randall (2004) argue for an expansive, public insurance-like system:

This leads us to examine alternative ways that the financial resources available to automobile accident victims might also be available to benefit victims of domestic and sexual violence. This involves the reform of the criminal injuries compensation system and a clear articulation of a rationale for compensation. Given that this would involve significant public expenditure, and therefore political opposition, we also consider models for a private insurance response. Our conclusion is that the only viable solution to the gross under-compensation of those injured by acts of domestic and sexual violence in Canada, is a substantially enhanced public compensation scheme. (316)

If sexual assault survivors do not feel adequately compensated by the civil justice system, there is little hope for victims of street sexual harassment. One problem is that there is rarely any physical evidence. 
Further, unlike a rape at a house party, where witnesses may have a personal connection with the complainant, there is not necessarily a personal connection with witnesses on a public street corner. Legal remedies in civil suits are aimed to put the Plaintiff in the situation they would have been in but for the wrong done to them. Courts have struggled to adequately award damages to sexual assault survivors seeking to be put in the situation they would have been in prior to the acute attack; street sexual harassment survivors have even less reason for hope. Compensable losses due to street sexual harassment too often result from cumulative experiences and are, therefore, too multi-causational to satisfy the tort framework.

DB et al. v. Johnson (2012) is one Canadian civil litigation case related to street sexual harassment that proved a success. Various plaintiffs filed a claim against their neighbour for damages arising from assault, battery, and intentional infliction of mental suffering. The behaviour included making lewd sexual suggestions and comments, verbal sexual harassment, inappropriate touching (such as grabbing breasts and buttocks, sometimes in public). The Court commented that " $\mathrm{t}]$ he whistling, catcalls and insults by themselves, however objectionable, cannot support a claim for damages." Nonetheless, the Court decided that "non-consensual touching aside, each of the female plaintiffs, satisfied me that they had suffered humiliation and intimidation and an apprehension of sexual assault." The Court assessed damages at between $\$ 350$ and $\$ 5,500$ per plaintiff. Unhelpfully, this victory was only possible because there was an identifiable Defendant making continuous and traceable assaults. It is also worth noting that the Defendant did not defend in the action.

A British Columbia report on civil remedies in cases of sexual assault recommends extending the bases for liability to include negligence, vicarious liability, and breach of non-delegable duty (British Columbia Law Institute 2001). An expanded conception of sexual assault and its causes increases the chances of remedies for survivors. It also increases potential street sexual harassment recovery when combined with growing class action capacity in Canada.

The basic purpose of class action law is to change the costs and benefits in any legal situation so plaintiffs can band together to distribute the costs of litigation across a number of Plaintiffs who each have a right to a remedy that would not individually be sizeable enough to warrant a law suit. Companies that might normally breach their duties because the harm to an individual customer would not merit an expensive action become justly exposed to their aggregate liability (Canadian Bar Association: BC Branch 2017).

Street sexual harassment class action suits could use traditional negligence and vicarious liability law to build class actions against the actors whose inertia facilitates street sexual harassment. Examples might include outdoor construction companies that refuse to act against staff or contractors who sexually harass passersby, municipalities whose inaccurate transit schedules leave women vulnerable for long periods of time, or bars that, instead of calling the police, eject harassing patrons who then move to verbally harass others in the public sphere.

Overall, private tort law has struggled to account for women. Margot Schlanger (2002) has explored the reasonable person standard in torts and its bias toward what men deem reasonable. Martha Chamallas' research has determined that "the negligent infliction of emotional harm and negligent interference with relationships are low in the hierarchy of compensable harms, in part because of their cognitive link to women and women's injuries" $(2005,4)$.

Remedies for gender-based violence are no different. In "Gendered Harms and the Law of Tort: Remedying (Sexual) Harassment," Joanne Conaghan identified structural concerns within tort law:

It may be precisely because the law recognizes the "wrong" inherent in defamation that it is socially perceived; it may be because the law denies a remedy for many of the acts which constitute sexual harassment that it is too often 
socially denied. In other words harm is socially constructed and legally constituted; unless a harm is recognized as such by society and by law, it is not experienced as such. That is why for years many women have put up with sexual harassment without complaint: the social and legal failure to recognize the injury entailed has led women simply to endure it, repressing their feelings of violation, incipient outrage, the sense that a wrong had been perpetrated [footnotes removed]. (1996, 429)

Even established gender-based harms struggle within status quo tort law; new concepts such as street sexual harassment face many challenges. Though Conaghan (1996) and Brown and Randall (2004) argue for a continued use of tort law as part of the feminist project, this article argues it cannot be the only avenue for upheaval, particularly where street sexual harass- ment is concerned. The threshold for intention in any torts - albeit on the balance of probabilities - may be too onerous in most cases of street sexual harassment.

\section{ii. Public Law}

The criminal law also has a poor record addressing gender-based violence. Sexual assault rates are disturbingly high and convictions disturbingly low; this has been driven by many factors related to systemic misogyny in the policing and judicial establishments (Randall 2004). The outcome for more fleeting forms of gender violence, such as street sexual harassment, remains an open question. The following portion of the article will address specific sections of Canada's Criminal Code. There is no Code provision squarely focused on street sexual harassment.

\section{Section 265. Assault}

The s.265 sexual assault provision of the Criminal

\section{Assault}

265. (1) A person commits an assault when

(a) without the consent of another person, he applies force intentionally to that other person, directly or indirectly;

(b) he attempts or threatens, by an act or a gesture, to apply force to another person, if he has, or causes that other person to believe on reasonable grounds that he has, present ability to effect his purpose; or

(c) while openly wearing or carrying a weapon or an imitation thereof, he accosts or impedes another person or begs.

Application (2) This section applies to all forms of assault, including sexual assault, sexual assault with a weapon, threats to a third party or causing bodily harm and aggravated sexual assault.
Harassment/Stalking

264. (1) No person shall, without lawful authority and knowing that another person is harassed or recklessly as to whether the other person is harassed, engage in conduct referred to in subsection (2) that causes that other person reasonably, in all the circumstances, to fear for their safety or the safety of anyone known to them

Prohibited conduct 2) The conduct mentioned in subsection (1) consists of

(a) repeatedly following from place to place the other person or anyone known to them; $(b)$ repeatedly communicating with, either directly or indirectly, the other person or anyone known to them; $(c)$ besetting or watching the dwelling-house, or place where the other person, or anyone known to them, resides, works, carries on business or happens to be; or (d) engaging in threatening conduct directed at the other person or any member of their family.
Public Indecency 173. (1) Everyone who wilfully does an indecent act in a public place in the presence of one or more persons, or in any place with intent to insult or offend any person,...

175. (1) Every one who (a) not being in a dwellinghouse, causes a disturbance in or near a public place, (i) by fighting, screaming, shouting, swearing, singing or using insulting or obscene language, (ii) by being drunk, or (iii) by impeding or molesting other persons, $(b)$ openly exposes or exhibits an indecent exhibition in a public place, $(c)$ loiters in a public place and in any way obstructs persons who are in that place,...
Common Nuisance 180. (1) Every one who commits a common nuisance and thereby

(a) endangers the lives, safety or health of the public, or

(b) causes physical injury to any person,...

(2) For the purposes of this section, every one commits a common nuisance who does an unlawful act or fails to discharge a legal duty and thereby

(a) endangers the lives, safety, health, property or comfort of the public; or (b) obstructs the public in the exercise or enjoyment of any right that is common to all the subjects of Her Majesty in Canada

Image 3: This chart provides a short form of the key Criminal Code provisions that could be argued to be applicable to street sexual harassment. 
Code does not work well for street sexual harassment because street sexual harassment involves words and not physical touching or force, as described under s.265.1(a). Under s.265.1(b), any act or gesture that is reasonably perceived as a subjective threat could be considered assault. So, although the collection of street sexual harassment experiences in a woman's life may be threatening on the whole, each incident will likely seem too benign to reach the s.265 threshold. Highly menacing sexual harassment-even on the street—could reach this threshold, however.

\section{Section 264. Harassment}

The s.264 criminal harassment provision is often called the anti-stalking provision. However, much research exists on the section's deep inadequacy in addressing stalking (for example, see MacFarlane 1997). Section 264 sets too high a threshold for use against street sexual harassment. The Code requires "repeated" acts. Although women's lived experiences of street sexual harassment are repeated, the perpetrator is usually different in each instance. Because the Code historically requires that a single harasser attack the same women repeatedly, street sexual harassers who randomize their attacks on different women receive impunity under this current provision.

\section{Section 173. Indecency}

The public indecency sections of the Code hold potential to curb street sexual harassment. Street sexual harassment is instinctively-as the harm discussed above provides — an indecent act. Unfortunately, despite a rich body of statutory interpretation, indecency has never been thoroughly interpreted through a feminist lens. ${ }^{1}$ Anti-pornography issues involving decency have focused on overall threats to women, but within the community standards test. The community standards test is a judicial endorsement of tyranny of the majority. This is demonstrated by the Court's recognition that public opinion surveys may be appropriate to measure "a general average of community thinking and feeling" $(R v$. Labaye 2005). The court has focused on the "harm" issue within the community standards test, arguing that social norms are not determinative ${ }^{2}$ but this half-measure is insufficient.
Lise Gotell cites Jeffrey Weeks in her deconstruction of the Butler decision. In $R v$. Butler, Butler, a Manitoba video storeowner, was convicted under the Criminal Code obscenity law for distributing pornographic videos. Butler claimed the Code violated his constitutional right to freedom of expression. The Court upheld the obscenity law as a justifiable restriction on freedom of expression. Weeks (and then Gotell) wrote: "Moral panics are flurries of social anxiety, usually focusing on a condition or person, or a group of persons, who have become defined as a threat to accepted social values and assumptions" (Weeks 1986, 95). Gotell (1997) notes that the Butler factum submissions embody the core problem with the community standards test:

The role of law as guardian of the moral universe is clearly defended and applauded in each of these factums. Implicit here is the assumption that the depiction of sexual practices that lie outside of majoritarian norms constitutes a threat to the community itself. (53)

Although some feminists interpreted Butler as a victory, the victory is steeped in a problematic legal framework. Queer theorists such as Brenda Cossman (2004) contend that Butler did not apply a feminist lens to community standards. As Gotell (1997) states, "Butler merely provide[d] a new feminist language to legitimize and modernize what is really an old conservative, moral agenda" (at 99).

Community standards tests such as those discussed in Butler - even those that purport to focus on harm over norms-are antithetical to feminism. Community standards embody normative social codes of conduct that have oppressed women throughout Anglocentric history. The weakness of the community standards test is directly linked to indecency, a concept that has for years been used to regulate women's behaviour through government-sponsored regulation of sexual and artistic preferences. The decency provisions are also steeped in gender roles: the male-dominated legislature and courts are here to protect women and children from exposure to culture that is unseemly and "slutty." More modern interpretations of inde- 
cency based on community standards and harm have facially attempted to move away from embodying majority preferences, but feminists have effectively exposed such court claims (Cossman 1997). I contend that such decency provisions are the sword of moral panic and a key tool in regulating women's sexual behaviour. To call on legal definitions of decency and community standards to protect women against street sexual harassment therefore seems counterproductive. The Criminal Code, as the book of rules to indicate social condemnation of behaviours, should focus on the harassers, not on the socalled decency of the harassed.

I suggest that the courts and the legislature should avoid the community standard in reviewing the decency of street sexual harassment according to s.173(1) and move toward a more feminist focus on the agency of each individual woman. Leading scholars in the US have similarly argued for a sexual harassment doctrine that employs a reasonable person standard that accounts for complainants' intersectional identities (Onwuachi-Willig 2018).

The relevant "flashing" provision, under section 1.75(b) of the Criminal Code, will not be considered under the scope of this paper because "flashing" is an obvious and recognized form of extreme street sexual harassment. The "flashing" sections state that anyone who (a) causes a public disturbance by shouting, using insulting language, using obscene language, or molesting another is guilty of disorderly conduct, and any person who (c) loiters in public and obstructs persons who are in the same place is committing a crime.

Either (a) or (c) could be used to criminalize street sexual harassment. Even if the harassment is not as obviously acute or offensive as flashing, an action that disturbs a woman in public should be considered a disturbance if she feels the language directed to her was insulting, obscene, or bothersome (the traditional definition of molestation) sufficient to satisfy ss.173175. Finally, any street sexual harassment that results in a woman feeling uncomfortable while walking her preferred public route should be considered obstruction. To make a woman uncomfortable in public is a core kind of obstruction. Obstructing women's free participation in the public sphere is central to the negative impact of street sexual harassment. In this way, ss.173-175 are the most fitting response to street sexual harassment.

To properly capture and condemn street sexual harassment, the public indecency provisions provided in ss. 173-175 should be made more generic to encompass verbal indecency, or the list of indecent acts should be expanded beyond such physical acts as flashing to explicitly include indecent verbal assaults.

\section{Section 180. Nuisance}

Section 180 is the last potential option to criminalize street sexual harassment. Satisfying subsection (a) requires viewing street sexual harassment as endangering women's health and comfort. It also requires viewing the (predominantly female) victims as members of the public. This should be straightforward. However, the legal community has a history of accepting the male viewpoint as the norm and actively asserting the male right, under and in the law, not to know about the experiences of women. Feldthusen (1990) references the danger present when a dominant group assumes, uses, or imposes their narrative as the neutral viewpoint: " $[\mathrm{M}]$ most male law professors still refuse to consider, let alone engage with, the issues. Instead they exercise the male 'right not to know': to ignore, deny, neuter, trivialize, and redefine gender issues in legal education" (70-71).

\section{Envisioning a New Code Provision}

As is evident from the above discussion, there is no Code provision squarely focused on street sexual harassment. None of the existing laws are easily adaptable. Overall, the indecency and nuisance portions of the Code seem prima facie more useful than the assault or harassment portions.

In two recent cases, the Canadian Courts have ad- 
dressed possible use of the Code provisions to penalize street sexual harassment. In $R v$. Kohl, the complainant was jogging when the accused, a stranger to her, jumped out from behind bushes and blocked her way in a threatening and frightening manner; the accused did not touch her or speak to her. The complainant ran away and the accused chased her down the street. When the complainant ran to a house to seek help, the accused stood at the end of the driveway and stared at her. The complainant stated that she was very frightened. In this case, the accused was convicted of criminal harassment under s.264(2)(d) and was sentenced to three years' imprisonment. He appealed the conviction and the sentence. The appeal of the conviction was dismissed, but the sentence appeal was allowed to reduce the sentence to two years, with conditions. This is an extreme case of street sexual harassment that met the threshold for criminal harassment as envisioned by the Code.

In $R v$. Burns, the perpetrator whistled at the complainant and said "nice butt" or "nice ass." After the complainant ran to get away, the Appellant called out, "Are those pants painted on?" The Appellant was acquitted of the conviction for harassment, with the Court noting:

While the [perpetrator's] conduct was clearly inappropriate and unwanted, we do not see the incident as amounting to threatening conduct within the meaning of those words in s.264(2)(d). Although the complainant justifiably felt upset and scared by the appellant's conduct, viewed objectively, we do not see it as rising to the level of a "tool of intimidation designed to instill a sense of fear. ( $R v$. Burns)

This Court decided that this very common example of street sexual harassment did not warrant sanction under the Code.

Despite inadequacies, criminal law stands as our society's main mechanism to condemn actions. I therefore contend that the Canadian legislature should enact new criminal laws against street sexual harassment. Street sexual harassment provisions may not be easy to prosecute, but neither are many provisions of the Criminal Code regarding sexual violence. Condemnation under the Code is an important start to establishing the basic type of conduct that will not be tolerated. A new provision eschews the need to re-envision older provisions alongside unbiased statutory interpretation.

The struggle to recognize sexual harassment is amplified by the law's chosen human rights approach, which requires the right be tied to a status; for example, that of an employee. This caveat hinders the full protection of dignity that women deserve in all roles and situations. The advantage of a criminal law approach to street sexual harassment is that it codifies the breach of attacks on dignity across the citizen experience.

\section{i. Looking Internationally}

Many jurisdictions around the world have taken action to curb sexual harassment and provide helpful lessons or ideas that Canada should consider. For example, in 2010, UN Women launched targeted programs to increase women's public safety in Ecuador, Egypt, India, Papua New Guinea, and Rwanda (United Nations 2010). In 2014, the Nepal police implemented a focused campaign to curb sexual harassment on public buses. Police register complaints and file reports regarding the places and circumstances of harassment (Stop Street Harassment 2014). In the District of Columbia, it is now illegal to engage in abusive language or conduct that disturbs a person's path through a public space (Badger 2014). In March 2015, Peru passed an anti-sexual harassment law that states that any act or threat affecting the freedom and dignity of movement and the right to physical and moral integrity of vulnerable peoples is harassment and punishable (Steinkellner 2015). Belgium and Portugal have made it illegal to sexually harass or intimidate a person and violation of the law is punishable by a fine of up to one year in prison; Portugal has made it three years if the victim of harassment is younger than 14 years (King 2016). In November of 2017, Belgium handed its first court judgment related to street harassment. The state fined a man nearly $€ 3000$ for harassing a female police officer (Flanders Today 2018). 
Many jurisdictions have taken the route of ticketing for street sexual harassment. In partial response to the \#MeToo movement, France has passed legislation which will target several forms of sexual harassment, including street harassment. The new law will ban "insulting, intimidating, threatening and following women in public spaces," any of which can lead to a fine of up to $€ 750$. France's junior minister for gender equality, Marlène Schiappa, stated, "Harassment in the street has previously not been punished. From now on, it will . . f forbid insulting, intimidating, threatening and following women in public spaces" (Politico 2017; Harper's 2018.)

There are some significant drawbacks, however, to a ticket-based regime, including the potential for bias in implementation and the potential for disproportionately targeting marginalized groups (White 2018). Further, a ticketing system may undermine any message the state intends to make about the seriousness of street sexual harassment. Compared to the more common breaches that result in tickets-speeding, parking incorrectly, riding a bicycle without a helmet-tickets send no strong message about society's unwillingness to accept a particular behaviour.

\section{ii. Recent Canadian Developments}

In March 2017, the Standing Committee on the Status of Women conducted a study on violence against young women and girls in Canada and presented their findings and recommendations to parliament (House of Commons 2017). The committee provided 45 recommendations to help prevent genderbased violence. A few recommendations recognized the lack of research on street harassment and called for the Government of Canada to fund initiatives, including new research and analysis of existing research that addresses intersectional violence, street harassment, and sexual harassment in public spaces and its effects on women (House of Commons 2017).

The Government of Canada proposed Bill C-309, An Act to Establish Gender Equality Week, to recognize certain hardships faced by women. The Act proclaims the last week of September each year in Canada as "Gender Equality Week." The Bill received Royal As-
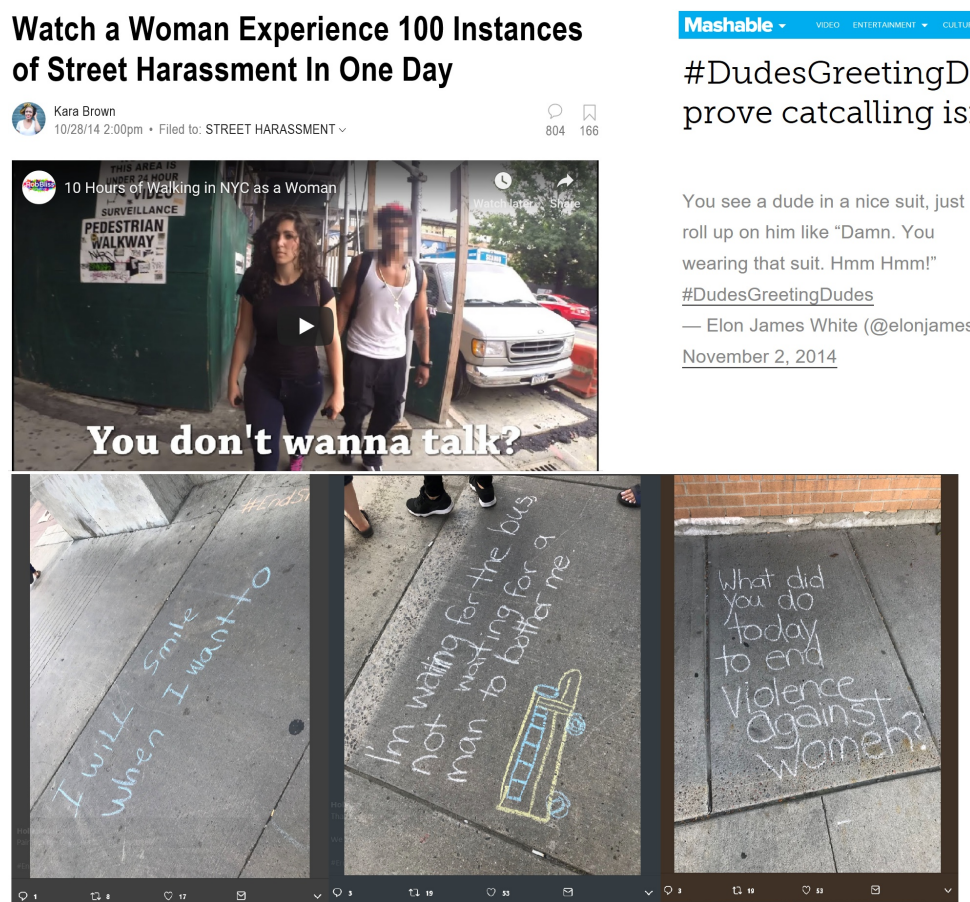

\#DudesGreetingDudes uses humor to prove catcalling isn't just a friendly hello

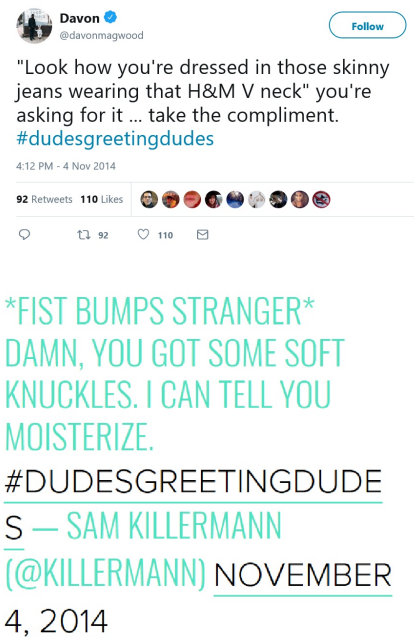

4, 2014

Image 4. This graphic shows some of the activist work being done to bring street sexual harassment to the fore. (Hui 2015; Brown 2014; Killermann 2014; Magwood 2014; Romano 2014; White 2014; Jurecko 2016; Crosby 2017; Gillis 2018). 
sent on June 21, 2018, and September 2018 saw the first Gender Equality Week. The notable feature about this Act is that 2016 debates on the issue reflect recognition of "[c]atcalling, harassment on the street, slut shaming, [and] victim blaming" as commonplace, and that "[w]e need to raise the bar on those" (House of Commons Debates 2016). Yet, notably, the Act itself does not explicitly recognize street harassment.

Kiera Liblik has noted that Canada has ratified the Convention on the Elimination of All Forms of Discrimination Against Women (CEDAW), a UN document focused on eliminating sex-based discrimination, and has suggested that failing to criminalize street harassment would be against the interests of CEDAW (Liblik 2015).

\section{Conclusions}

Many women's organizations, including Women in Cities International and Hollaback!, are helping to share personal stories and raise consciousness about street sexual harassment. Street sexual harassment is an affront to human dignity and the right to participate freely in the public sphere, a basic civil liberty. Street sexual harassment-and the lack of legal response to it-is therefore an ongoing denial of basic rights. The shift in awareness and recognition of workplace sexual harassment provides some hope for similar change regarding street sexual harassment. However, judicial systems still struggle to bring justice to women survivors of workplace harassment. No current Canadian law may be sufficient to address street sexual harassment, due to historical bias in construction and application of the law. New criminal laws are therefore required. Other jurisdictions are enacting stronger anti-street harassment provisions than Canada. It is time for our legislators to lead on women's right to dignity in public.

\section{Endnotes}

1. The Butler decision is one of the better-known indecency decisions. This article will refer to Butler because it engages core questions around indecency. Little Sisters Book and Art Emporium v. Canada (Minister of Justice) [2000] 2 SCR 1120 is an equally relevant and concerning decision.

2. Craig (2009) states: "Chief Justice McLachlin determined in Labaye that the type of harm identified in Butler (that being 'conduct which society formally recognizes as incompatible with its proper functioning') must be assessed not by community standards of tolerance, but rather by those norms which our society has formally recognized in the constitution or similar fundamental laws: 'The inquiry is not based on individual notions of harm, nor on the teachings of a particular ideology, but on what society, through its fundamental laws, has recognized as essential. Views about the harm that the sexual conduct at issue may produce, however widely held, do not suffice to ground a conviction. This is not to say that social values no longer have a role to play.'” [footnotes removed]

\section{Acknowledgements}

I wish to thank Alexandra Heine, Mikayla Hill, Sydney Olsen, Victoria Rudolf, and, in particular, Gitanjali Keshava and Darci Stranger for their research assistance. 


\section{References}

Allen, Robert L. 1995. "Stopping Sexual

Harassment: A Challenge for Community

Education." In Race, Gender, and Power in America:

The Legacy of the Hill-Thomas Hearings edited by

Anita Hill \& Emma Coleman Jordan, 129. Oxford:

University Press.

Alston, Lauren. 2012. "State of the Streets: Alberta, Canada.” Hollaback.org.

http://www.ihollaback.org/?s=canada.

American Psychological Association. 2007. "Task

Force on the Sexualization of Girls Report."

http://www.apa.org/pi/women/programs/girls/report

.aspx.

Badger, Emily. 2014. "Harassing women on the street isn't just offensive. It's also often illegal."

Washington Post (October 29, 2014).

http://www.washingtonpost.com/blogs/wonkblog/w p/2014/10/29/catcalling-women-on-the-street-isntjust-offensive-its-also-often-illegal/.

Baumgardner, Jennifer and Amy Richard. 2000. Manifesta: Young Women, Feminism, and the Future. 1st Ed. New York: Farrar, Straus and Giroux.

Boosil, Samantha (@samanthadjb).2015. Twitter Post. May 28, 2015.

Bowman, Cynthia Grant. 1993. "Street Harassment and the Informal Ghettoization of Women."

Harvard Law Review 106 (3): 520-21.

British Columbia Law Institute. 2001. "Civil Remedies for Sexual Assault - A Report prepared by the British Columbia Law Institute for its Project Committee on Civil Remedies for Sexual Assault." BCLI Report No. 14.

Brown, Craig and Melanie Randall. 2004.

"Compensating the Harms of Sexual and Domestic Violence: Tort Law, Insurance and the Role of the
State." Queen's Law Journal 30: 311-347.

Brown, Kara. 2014. "Watch a Woman Experience 100 Instances of Street Harassment in One Day." Jezebel.com. http://jezebel.com/watch-a-womanexperience-100-instances-of-street-harass1651800051.

Campbell-Fowler v. Royal Trust Co., [1993] CanLII 7165 (AB QB). 1993.

Canadian Bar Association, British Columbia Branch. "What is a class action lawsuit?" CBABC.org. http://cbabc.org/For-the-Public/Dial-ALaw/Scripts/Credit-Debt-and-Consumer/233.

Chamallas, Martha. 2005. "Civil Rights in Ordinary Tort Cases: Race, Gender, and the Calculation of Economic Loss." Loyola of Los Angeles Law Review 38: 1435-1468. . 2012. Introduction to Feminist Legal Theory. 3rd ed. New York: Aspen Publishers.

Collazo, Abigail. 2013. "True Story: I Was Sexually Harassed at The Corner Store."

StopStreetHarassment.org. http://www.stopstreetharassment.org/2013/05/harasse datcornerstore/.

CompleteStreetsCat (@sheridesabike).2015. Twitter Post. May 28, 2015, 7:20am

Conaghan, Joanne. 1996. "Gendered Harms and the Law of Tort: Remedying (Sexual) Harassment." Oxford Journal Legal Studies 16 (407): 429.

Cossman, Brenda. 1997. "Feminist Fashion or Morality in Drag? The Sexual Subtext of the Butler Decision." In Bad Attitudels on Trial: Pornography, Feminism, and the Butler Decision edited by Brenda Cossman, Shannon Bell, Lise Gotell, and Becki Ross, 107-151. Toronto: University of Toronto Press.

Craig, Elaine. 2009. "Laws of Desire: The Political 
Morality of Public Sex." McGill Law Journal 54 (355): 361.

Criminal Code, R.S.C. 1985 , c. C-46.

Crosby, Jennifer. 2017. "Interactive exhibit shows Edmonton's cat-calling street harassers what it feels like." Global News. https://globalnews.ca/news/3898406/exhibitedmonton-catcalls-street-harassers-what-it-feels-like; see also https://thisiswhatitfeelslikeproject.com/

DB et al v. Johnson, [2012] 566 U.S. 1. 1-7. 2012.

Demeyere, Gillian. 2005. "Common Law Actions for Sexual Harassment: The Jurisdiction Question Revisited." Queen's Law Journal 8 (637): 647, 663.

Feldthusen, Bruce. 1990. "The Gender Wars: Where the Boys Are." Canadian Journal of Women and the Law 4 (1): 66.

Flanders Today, 2018. "First Verdict of Verbal Sexual Harassment Handed Down In Belgium." Flanders Today (March 6, 2018).

http://www.flanderstoday.eu/current-affairs/firstverdict-verbal-sexual-harassment-handed-downbelgium

Fonder, Tom. 2014. Attention Cartoon. January 28, 2018. Happy Jar.

http://www.happyjar.com/comic/attention/

Fox, Naomi. 2016. "Street Harassment Isn't a Compliment." Canadian Women's Foundation (August 16, 2016). https://www.canadianwomen.org/blog/streetharassment-isnt-a-compliment/

Gabel, Peter. 1992. "Reification in Legal Reasoning." In Critical Legal Studies edited by James Boyle, 18. Cambridge: Dartmouth Publishing.

Gender Equality Week Act, SC 2018 c.14.
Gillis, Megan. 2018. "Hollaback takes to the street with chalk at weekend walk." Ottawa Citizen (August 13, 2018). https://ottawacitizen.com/news/localnews/hollaback-takes-to-the-street-with-chalk-atweekend-walk.

Gotell, Lise. 1997. "Shaping Butler: The New Politics of Anti-Pornography." In Bad Attitude/s on Trial: Pornography, Feminism, and the Butler Decision, edited by Brenda Cossman, Shannon Bell, Lise Gotell \& Becki Ross, 53. Toronto: University of Toronto Press.

Harper's Bazaar. 2018. "Catcallers will not be fined $€ 750$ on the spot in France." Harper's Bazaar. https:/www.harpersbazaar.com/uk/culture/a2263355 $3 /$ catcallers-will-now-be-fined-euro750-on-the-spotin-francel.

Hollaback! Ottawa. 2013. "Our city, our space, our voice: A report on street sexual harassment." July 2013.

https://ottawa.ihollaback.org/files/2013/07/Our-cityour-space-our-voice.pdf.

House of Commons Debates, 42nd Parliament, 1st Session. 2016. 109 (17 November 2016) at 6905. http://www.ourcommons.ca/DocumentViewer/en/42 $-1 /$ house/sitting-109/hansard

House of Commons Publication. 2017. Taking Action to End Violence Against Young Women and Girls in Canada.

http://www.ourcommons.ca/Content/Committee/42 1/FEWO/Reports/RP8823562/feworp07/feworp07e.pdf.

Hui, Stephen. 2015. "Hollaback volunteers to count street harassment incidents in Vancouver." The Straight (April 9, 2015).

http://www.straight.com/news/428711/hollabackvolunteers-count-street-harassment-incidentsvancouver/.

Janzen v. Platy Enterprises Ltd., [1989] 1 S.C.R. 1252. 1989. 
"Julie Webb v. Cyprus Pizza." Canadian Human Rights Reporter 6, decision 444 (1985): D2794-97. Toronto: Canadian Human Rights Reporter.

Jurecko, Alexandra. 2016. "Canada: Sexual Harassment in Montreal and Efforts against it." (2016) SSH Blog Correspondent. http://www.stopstreetharassment.org/2016/09/shmo ntreal

Killermann, Sam (@Killermann).2014. Twitter post. November 4, 2014, 1:49pm

King, Elizabeth. 2016. "6 Countries That Are Fighting Back Against Catcalling." Complex.com (January 2, 2016).

https://www.complex.com/life/2016/01/international -catcalling-policies/

Lajoie v. Kelly [1997] 32 C.C.L.T. 115. 1997.

Laxer, Michael. 2013. "Sexual harassment on the street: Taking misogynist hate speech seriously." Rabble.com (June 24, 2013).

http://rabble.ca/blogs/bloggers/michaellaxer/2013/06/sexual-harassment-on-street-takingmisogynist-hate-speech-seriously

Lewak, Doree. 2014. "Hey, ladies - catcalls are flattering! Deal with it." New York Post (August 18, 2014). http://nypost.com/2014/08/18/enoughsanctimony-ladies-catcalls-are-flattering/.

Liblik, Kiera. 2015. "Catcalling: should it be criminal?" Queens Journal (June 30, 2015). https://www.queensjournal.ca/story/2015-0630/opinions/catcalling-should-it-be-criminal/

Livingston, Beth. 2014. Cornell International Survey on Street Harassment.

https://www.ihollaback.org/cornell-internationalsurvey-on-street-harassment/

LSUC, Law Society of Upper Canada Department of Continuing Legal Education. 1992. "Workplace
Sexual Harassment" at D-2.

MacKinnon, Catharine A. 1983. "Feminism, Marxism, Method, and the State: An Agenda for Theory." Signs: Journal of Women in Culture and Society 8 (4): 635-36.

1987. Feminism Unmodified. Cambridge, Mass.: Harvard University Press.

MacFarlane, Bruce. 1997. "People who stalk people." University of British Columbia Law Review 94: 89-90.

Magwood, Devon (@devonmagwood). Twitter post. November 4, 2014.

Moore, Tracy. 2015. "Shame, Embarrassment, Hiding: Your Stories of Dudes Checking You Out." Jezebel.com (April 28, 2015).

http://jezebel.com/shame-embarrassment-hidingyour-stories-of-dudes-che-1700468557.

Oddone-Paolucci, Elizabeth, Mark Genuis, and Claudio Violato. 2000. "A Meta-Analysis of the Published Research on the Effects of Pornography." National Foundation for Family Research and Education, University of Calgary.

Onwuachi-Willig, Angela. 2018. "What About \#UsToo: The Invisibility of Race in the \#MeToo Movement." Yale Law Journal Forum 128:105.

Oshynko, Norma Anne. 2002. NO SAFE PLACE: The Legal Regulation of Street Harassment. MA Thesis, University of British Columbia.

Parry, Diana (ed). 2018. Feminisms in Leisure Studies: Advancing a Fourth Wave. United Kingdom:

Routledge.

Politico. 2017. "France: 'We'll make cat-calling a punishable offence." Politico.eu. https://www.politico.eu/article/france-genderequality-well-make-cat-calling-a-punishable-offense/ 
R v. Burns, [2007] O.J. 5117, 2007.

R v. Butler, [1992] 1 S.C.R. 452, 1992.

R v. Kohl, [2009] 94 O.R. (3d) 241, 2009.

R v. Labaye, [2005] 3 S.C.R. 728, 2005.

Randall, Melanie. 2004. "Sexual Assault Law, Credibility, and 'Ideal Victims': Consent, Resistance, and Victim Blaming." Canadian Journal of Women and the Law 22 (2): 405.

Romano, Andrea. 2014. "\#DudesGreetingDudes uses humor to prove catcalling isn't just a friendly hello." Mashable.com (Nov 5, 2014). http://mashable.com/2014/11/05/dudes-greetingdudes/

Schlanger, Margo. 2002. "Gender Matters: Teaching a Reasonable Woman Standard in Personal Injury Law." Saint Louis University Law Journal 45 :769-78.

Seneca College v. Bhadauria, [1981] 2 SCR 181.

Sharp v. Seasons Restaurant, [1987], 8 C.H.R.R. D/4133.

Steinkellner, Kit. 2015. "All eyes on Peru, where street harassment is now a crime." Hello Giggles (March 10, 2015). http://hellogiggles.com/streetharassment-peru/

Stop Street Harassment. 2014. "Nepal: Public Transportation, A Hesitation to Women."

StopStreetHarassment.org. http://www.stopstreetharassment.org/2014/02/nepalpublictransport/

Stop Street Harassment. 2015. "What is Street Harassment." StopStreetHarassment.org. http://www.stopstreetharassment.org/about/what-isstreet-harassment/

Trudy. 2013. "Street Sexual Harassment and Post
Traumatic Stress Disorder.” GradientLair.com. http://www.gradientlair.com/post/63488882215/stree t-harassment-ptsd

United Nations Women. 2010. "Creating Safe Public Spaces." http://www.unwomen.org/en/what-wedo/ending-violence-against-women/creating-safepublic-spaces 